UDC [УДК] 625.1/.5

DOI 10.17816/transsyst20184432-43

(C) P. A. Plekhanov, V. V. Shmatchenko

Emperor Alexander I St. Petersburg State Transport University

(St. Petersburg, Russia)

\title{
STANDARDISATION OF MAGLEV TRANSPORTATION SYSTEMS IN RUSSIA
}

Existing regulatory framework in Russia does not include a full set of rules and standards needed, as the main document is absent - Safety Regulations Governing Maglev Transportation Systems. However, in this case the Russian Legislation provides for development and application of a special document, namely Special Technical Conditions (STC). These technical safety requirements to a capital construction object, that include either supplementary technical conditions to those which have not been set yet or are lacking in terms of safety, as well as deviations for the set requirements. Using the international and national experience, the authors and their colleagues have designed nine STC for MLTS. These are "General Design Requirements", "Guideway", "Substructure, Artificial Structures, Junctions and Crossings", "Terminals, Intermediate Stations, Maintenance Facilities and Buildings", "Propulsion and Power Supply System", "Train Control System", "Communication Systems", "Vehicles", "Integrated Safety System". Also, as a result of the study, the English-Russian (Russian-English) MLTS Explanatory Dictionary was compiled.

Keywords: Standardisation, Maglev Transportation Systems, Regulatory Framework, Special Technical Conditions (STC).

\section{(C) П. А. Плеханов, В. В. Шматченко}

Петербургский государственный университет путей сообщения Императора Александра I

(Санкт-Петербург, Россия)

\section{СТАНДАРТИЗАЦИЯ МАГНИТОЛЕВИТАЦИОННЫХ ТРАНСПОРТНЫХ СИСТЕМ В РОССИИ}

Сегодня в России нет полной нормативно-технической базы для создания магнитолевитационных транспортных систем (МЛТС), включая основной документ Технический регламент о безопасности магнитолевитационного транспорта. Вместе с тем российским законодательством предусмотрена разработка и применение особого рода документов - специальных технических условий (СТУ). Это технические требования в 
области безопасности объекта капитального строительства, содержащие дополнительные к установленным или недостающие технические требования по безопасности, а также отступления от установленных требований. Авторами и другими специалистами на основе мирового и отечественного опыта разработаны проекты девяти типовых СТУ для МЛТС: «Общие требования по проектированию», «Путь», «Основания для пути, искусственные сооружения, примыкания и пересечения», «Терминалы, промежуточные станции, служебно-технические здания и сооружения», «Система тяги и электроснабжения», «Система управления движением», «Система электросвязи и оповещения», «Подвижной состав», «Система комплексной безопасности». Кроме того, в результате проведенной работы подготовлен структурированный англо-русский (русско-английский) толковый словарь по МЛТС.

Ключевые слова: стандартизация, магнитолевитационные транспортные системы (МЛТС), нормативная база, специальные технические условия (СТУ).

\section{INTRODUCTION}

Magnetic Levitation Transport Systems (MLTS) is a further development of a conventional "wheel-rail" technology, the implementation of which requires development of respective regulatory framework for design, construction and operation. The MLTS related specific issues, namely traction, levitation, lateral stabilisation, power supply systems as well as overall safety, should receive special attention.

As of today, the world operates several passenger MLTS predominantly in the Eastern Asia states: Japan (Nagoya, Yamanashi), the Republic of Korea (Incheon), China (Shanghai, Changsha, Beijing). The realised MLTS projects are also present in the USA, Germany, and other states. The USSR conducted MLTS tests too.

In this regard, standardisation of MLTS in Russia should be carried out on the basis of the world experience and national practice of realisation of MLTS projects taking into account the active regulatory framework for design, construction and operation of transport systems.

\section{RUSSIAN SYSTEM OF NORMATIVE AND TECHNICAL REGULATION FOR DESIGN, CONSTRUCTION AND OPERATION OF TRANSPORT SYSTEMS}

The system of normative and technical regulation for design, construction and operation of transport systems in Russia encompasses normative legislative and normative technical documents (Fig. 1). At the same time, the structure and 


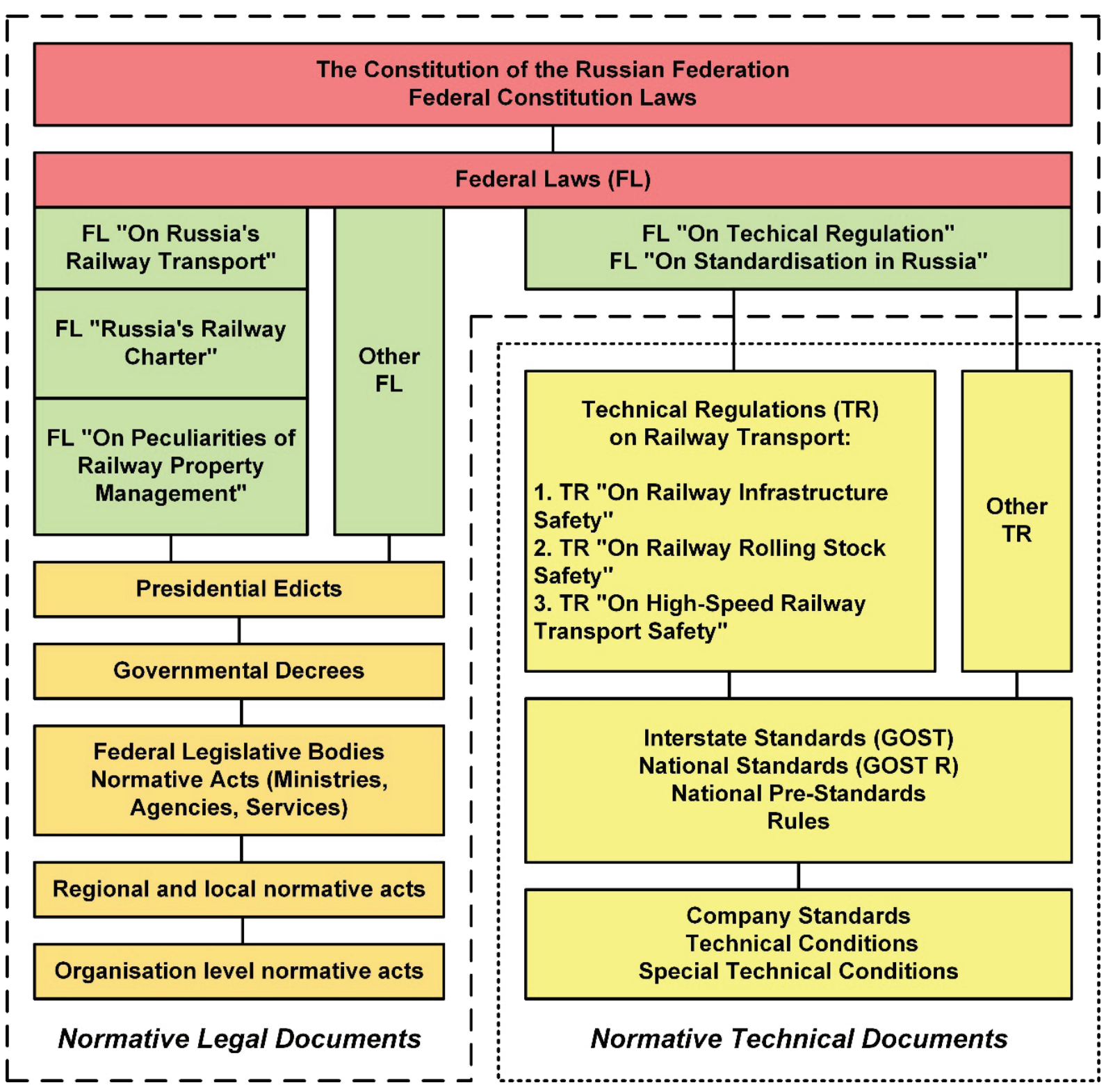

Fig. 1. The system of normative regulation for design, construction and operation of transport systems in Russia on the example of railway transport

composition of the Russian system of normative and technical regulation are determined by such normative legislative documents as Federal Laws "On Technical Regulation" and "On Standardisation in the Russian Federation" (Fig. 2).

At the upper sublevel of the state level of the system of normative technical regulation for safety the Technical Regulations (TR) are placed, which set mandatory requirements for product safety and life cycle processes. At the lower sublevel of the state level, there are Interstate Standards (GOST), National Standards (GOST-R), National Pre-Standards (PNST) as well as Norms and Rules (SP) voluntarily complied by to confirm meeting TR requirements. 


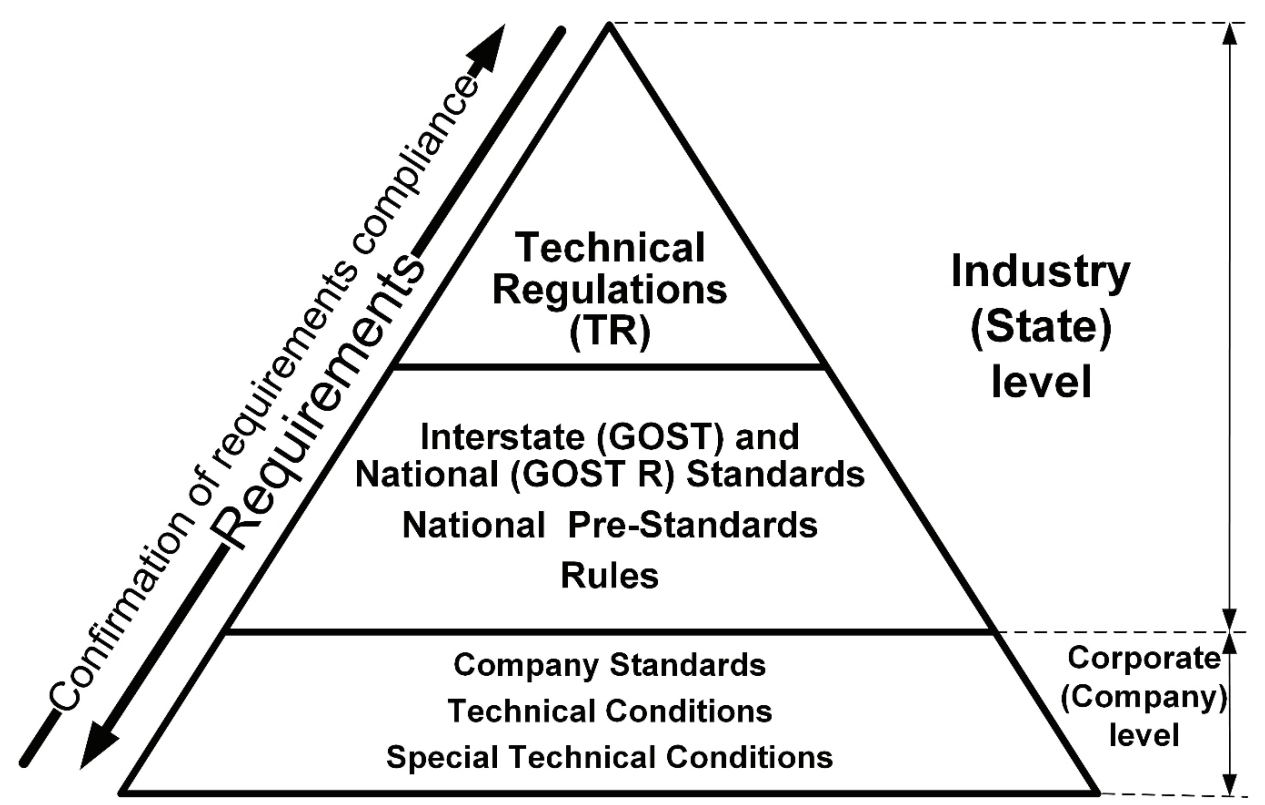

Fig. 2. The Russian system of normative technical regulation for safety

With the help of TR, the minimal required safety requirements are set, which qualitatively determine its necessary level. The quantitative indicators, which are used in manufacturing of production and certifying its life cycle processes compliance with these requirements, are contained in standards, and norms and rules, harmonised with the related TR. This approach enables making prompt corrections to qualitative characteristics in accordance with technical and technological changes, to ensure favourable conditions for innovations implementation. The standards as well as norms and rules met voluntarily are necessary to correctly understand and fulfill the mandatory requirements of the relative TR.

At a corporate level, it envisaged that various organisations should use their own normative technical documents: Company Standards (STO), Technical Conditions (TC), and Special Technical Conditions (STC) which will be covered further.

\section{FORMATION OF REGULATORY FRAMEWORK FOR MAGLEV DEVELOPMENT}

Today, Russia does not possess its own fully developed regulatory framework for design, construction, and operation of MLTS, which should comprise TR on maglev transport safety, GOST, GOST-R, PNST, and SP, containing requirements for subsystems and components of MLTS. However, some subsystems and components of MLTS come under separate TRs. These are, first of all, TRs such as "On Buildings and Structure Safety", "On Machinery and Equipment Safety", 
"On Low-Voltage Equipment Safety", "Electromagnetic Compatibility of Technical Equipment", and others. Associated with these TRs are standards, norms and rules supporting them, which cover corresponding subsystems and components of maglev transport.

At the same time, with regards to construction of unique engineering structures Russia's legislation provides for development and application of STCs, which are technical requirements for capital construction object safety and which contain supplementary technical safety requirements to those which have not been set yet or are lacking. The order of design and approval of STCs are determined by Order of the Ministry of Transport № 248/pr of April 15 $5^{\text {th }}, 2016^{\text {“ }}$ On Order of Design and Approval of Special Technical Conditions for Development of Project Documentation for Capital Construction Object", and "Guidelines "Order of Construction and Design of Special Technical Conditions for Development of Project Documentation for a capital construction object" (approved by Decision of the Regulatory and Technical Council of the Ministry of Regional Development of Russia, Protocol № 1 of February $1^{\text {st }}$, 2011).

Thus for application on passenger or freight maglev line to be constructed, STCs can be designed which should contain a register of forced deviations from active normative documents of Russia and the Eurasian Customs Union, justification of these deviations, and requirements for compensating activities. STCs may also include separate provisions of other countries' norms, provided that those meet Russian legislation.

It needs to be pointed out that STCs may become the basis for design of Technical Regulations on maglev transport safety and forming of the register of standards and rules to support them. This register should be formed after certain active documents have been determined, the application of which is feasible without updating them, and those which can be applied after updating and processing, as well as identification of the documents to be designed.

\section{DEVELOPMENT OF DRAFT STANDARD TECHNICAL CONDITIONS}

Considering the described conditions, on the basis of the international experience and national practice of delivery of maglev transport projects, the authors of this paper together with other specialists have designed a complex (or set? No, it is exactly the "complex") of nine draft standard STCs for design of MLTS [1], retaining the possibility to adapt them to a certain passenger or freight line (Fig. 3). 


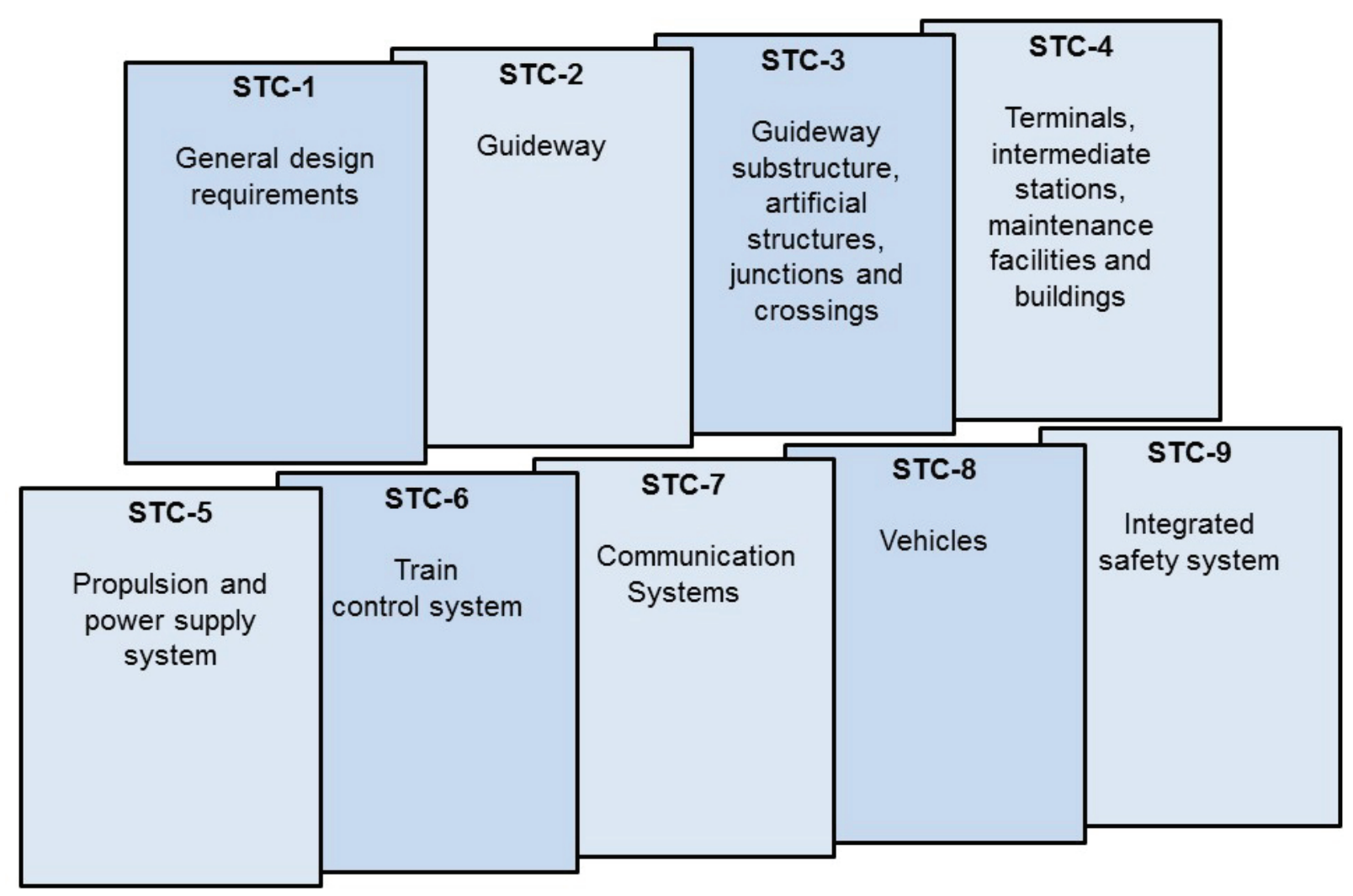

Fig. 3. Complex of draft standard STCs for maglev transport systems design

When designing the above-given STCs, apart from national developments and existing home-grown practice, the authors have broadly used the best international experience in this field. Thus, for instance, the details of requirements for MLTS design in terms of electromagnetic suspension are most comprehensively provided in the German Design Principles High-speed Maglev System. This is a major document [2], describing the Transrapid maglev passenger technology realised in Germany and China. The document provides requirements for the system as a whole, its vehicles, traction and power supply systems, operation control, and guideway. At the same time, the permanent magnet-based freight maglev transport technology, realised in USA by General Atomics, is described in the document [3] Conceptual Design Study for the Electric Cargo Conveyor (ECCO) System. Final Report. In a number of other documents, the descriptions of MLTS projects with various degree of realisation in different countries are given.

As a result of the study conducted, aimed at analysing and generalising the national and international experience, the English-Russian (Russian-English) Explanatory Dictionary was compiled, which contains terminology, definitions and requirements in design, construction and operation of maglev transport and may serve as a basis for preparation of a maglev transport course book. 
In the process of finalising STC and further working on standardisation of MLTS in Russia, it is necessary to use relative normative and technical documents (standards) of the countries that have already successfully delivered maglev transport projects: Germany (the European Union), USA, Japan, the Republic of Korea, China (Table 1).

Table 1. Standardisation systems of the countries (regions) that have realised maglev transport projects

\begin{tabular}{|c|c|}
\hline $\begin{array}{l}\text { Country } \\
\text { (region) }\end{array}$ & Standardisation system \\
\hline $\begin{array}{l}\text { EU member } \\
\text { states }\end{array}$ & $\begin{array}{l}\text { Each country has its own standardisation bodies. In the case of Germany, } \\
\text { for instance, its DIN. Any document that is issued by any standardisation } \\
\text { institute to be applied in a certain EU state, is subject to harmonising at } \\
\text { corresponding national and international levels. }\end{array}$ \\
\hline USA & $\begin{array}{l}\text { In USA the national standardisation system, including railway standards, are } \\
\text { managed by ANSI (American National Standards Institute). However, ANSI } \\
\text { does not design these standards but manages their design, performed by } \\
\text { governmental bodies, commercial and non-commercial organisations. The } \\
\text { USA standards can be roughly divided into the following basic groups: } \\
\text { - mandatory standards, which are designed by governmental bodies (e.g. } \\
\text { state defence sector) and which contain mandatory requirements; } \\
\text { - voluntary standards, which are designed by organisations and concerns for } \\
\text { application in a certain industry; } \\
\text { - special standards, which have a more limited scope of application than the } \\
\text { voluntary ones (the fact is that they are voluntary ones as well). }\end{array}$ \\
\hline Japan & $\begin{array}{l}\text { The Japanese Industrial Standards Committee (JISC). The country has } \\
\text { active national industrial standards (JIS), industry standards of industrial } \\
\text { associations, and corporate (company) standards. The national industrial } \\
\text { standards, which are occasionally reconsidered, are voluntary and are } \\
\text { specified in the form of industry standards. Corporate (company) standards } \\
\text { are designed using national and industry standards, taking into account } \\
\text { company's scope specifics and its products (services) delivered. }\end{array}$ \\
\hline $\begin{array}{l}\text { The } \\
\text { Republic } \\
\text { of Korea }\end{array}$ & $\begin{array}{l}\text { The Korean Agency for Technology and Standards (KATS), which designs } \\
\text { national standards (KS) in various industries. }\end{array}$ \\
\hline China & $\begin{array}{l}\text { The Standardisation Administration of China (SAC) undertakes } \\
\text { management of standardisation. The Chinese national standards are divided } \\
\text { into mandatory and voluntary. The latter one prevails, its application } \\
\text { is encouraged in every way. Besides, China also employs the so-called } \\
\text { "working standards" which validate the best practices of operation. }\end{array}$ \\
\hline
\end{tabular}


At this point, special attention should be given to MLTS safety issues. The existing world practices of securing transport systems' safety builds on application of a priori (forecast) and a posteriori (technical operation processes monitoring) risk estimates, including analysis of cause-and-effect relations and identification of pre-failures, negative tendencies and risk prerequisites. To realise these methods, the European Committee for Electrotechnical Standardization (CENELEC) has developed a number of framework documents. Today, as international standards the documents such as EN 50126 (IEC 62278), EN 50128 (IEC 62279) and EN 50129 (IEC 62425) are applied as the Specification and Demonstration of Reliability, Availability, Maintainability and Safety (RAMS) for transport systems and application guidelines. Apart from those, the standard to manage life cycle cost (Life Cycle Cost, LCC) IEC 60300-3-3 is also used (Table 2).

With regards to harmonisation of these documents in Russia, it needs pointing out that to date two national standards are approved:

- GOST-R MEK 62279-2016 Railways. Communication, signalling and data processing systems. Software for railway control and protection systems;

- GOST-R MEK 62280-2017 Railways. Communication, signalling and data processing systems. Safety related communication in transmission systems.

The developed project of GOST-R MEK 62278 (Determination and Confirmation of reliability, availability, maintainability and safety on railways) has not been approved as the national standard.

The issues relating to management of interrelated RAMS/LCC indicators, based on CENELEC approaches, have been reflected in the documents "Resources, risks and reliability management at life cycle stages" (URRAN)M which are undergoing implementation process at JSC "RZD", as well as in the following documents approved on their basis:

- GOST 33432-2015 Functional safety. Policy and programme of safety provision. Safety proof of the railway objects;

- GOST 33433-2015 Functional safety. Risk management on railway transport;

- GOST-R 33432-2015 Railway transport risks management. Classification of hazardous cases.

To interlink RAMS/LCC requirements with quality requirements in the unified business management system in an organisation, specialising in design, manufacture and operation of transport systems, the international standard ISO/ TS 22163:2017 Railway applications - Quality management system - Business management system requirements for rail organizations: ISO 9001:2015 and 
Table 2. Updated versions of basic normative documents on transport systems RAMS/LCC

\begin{tabular}{|c|c|}
\hline Item & Full title \\
\hline BS EN 50126-1:2017 [4] & $\begin{array}{l}\text { Railway Applications - The Specification and } \\
\text { Demonstration of Reliability, Availability, } \\
\text { Maintainability and Safety (RAMS) - Generic RAMS } \\
\text { Process }\end{array}$ \\
\hline BS EN 50126-2:2017 [5] & $\begin{array}{l}\text { Railway Applications - The Specification and } \\
\text { Demonstration of Reliability, Availability, } \\
\text { Maintainability and Safety (RAMS) - Systems } \\
\text { Approach to Safety }\end{array}$ \\
\hline IEC/TR 62278-3(2010) [6] & $\begin{array}{l}\text { Railway applications - Specification and demonstration } \\
\text { of reliability, availability, maintainability and safety } \\
\text { (RAMS) - Part 3: Guide to the application of IEC } \\
62278 \text { for rolling stock RAM }\end{array}$ \\
\hline IEC/TR 62278-4(2016) [7] & $\begin{array}{l}\text { Railway applications - Specification and demonstration } \\
\text { of reliability, availability, maintainability and safety } \\
\text { (RAMS) - Part 4: RAM risk and RAM life cycle } \\
\text { aspects }\end{array}$ \\
\hline IEC 62279(2015) [8] & $\begin{array}{l}\text { Railway applications - Communication, signalling and } \\
\text { processing systems - Software for railway control and } \\
\text { protection systems }\end{array}$ \\
\hline IEC 62425(2007) [9] & $\begin{array}{l}\text { Railway applications - Communication, signalling and } \\
\text { processing systems - Safety related electronic systems } \\
\text { for signalling }\end{array}$ \\
\hline PD CLC/TR 50506-1:2007 [10] & $\begin{array}{l}\text { Railway applications - Communication, signalling and } \\
\text { processing systems - Application Guide for EN } 50129 \\
\text { - Part 1: Cross-acceptance }\end{array}$ \\
\hline PD CLC/TR 50506-2:2009 [11] & $\begin{array}{l}\text { Railway applications - Communication, signalling and } \\
\text { processing systems - Application Guide for EN } 50129 \\
\text { - Part 2: Safety assurance }\end{array}$ \\
\hline PD CLC/TR 50451:2007 [12] & $\begin{array}{l}\text { Railway applications - Systematic allocation of safety } \\
\text { integrity requirements }\end{array}$ \\
\hline IEC 62280(2014) [13] & $\begin{array}{l}\text { Railway applications - Communication, signalling and } \\
\text { processing systems - Safety related communication in } \\
\text { transmission systems }\end{array}$ \\
\hline IEC 60300-3-3(2017) [14] & $\begin{array}{l}\text { Dependability management - Part 3-3: Application } \\
\text { guide - Life cycle costing }\end{array}$ \\
\hline
\end{tabular}


particular requirements for application in the rail sector is used. This document [15] is an updated version of the International Railway Industry Standard (IRIS).

\section{CONCLUSION}

Standardisation in Russia is expected to fully realise the key competitive advantages of maglev transport: fast passengers and freight delivery, higher capacities (at the expense of increased automation, i.e. "transport conveyor"), independency from external factors (other transport modes traffic, weather), adaption to landscape features, namely urban areas (as compared to conventional railway transport), low power consumption in the case of permanent magnets application (absence of rotating elements and transmission mechanisms), constant technology improvement and decrease of construction cost, environmental safety (low noise, vibration and dust pollution, urban compatibility), lack of barriers, which is natural for railways and highways.

The work should be continued to form the national technical regulatory framework for design, construction and operation of MLTS on the basis of international experience and national practice of delivery of MLTS projects.

\section{Библиографический список / References}

1. Шматченко В.В., Плеханов П.А., Роенков Д.Н., Иванов В.Г. Подготовка специалистов и разработка нормативной базы проектирования магнитолевитационных транспортных систем в России // Транспортные системы и технологии. - 2018. - Т. 4. - № 1. C. 138-154. [Shmatchenko VV, Plekhanov PA, Roenkov DN, Ivanov VG. Training of Specialists and Development of Design Regulatory Framework for Russian Magnetic Levitation Transport Systems. Transportation Systems and Technology. 2018;4(1):138154]. doi: 10.17816/transsyst2018041138-154.

2. Design Principles High-speed Maglev System (MSB). Information. Germany: Federal Railway Authority; 2008.

3. Conceptual Design Study for the Electric Cargo Conveyor (ECCO) System. Final Report. General Atomics (GA): Prepared for The Port of Los Angeles San Pedro, CA; 2006 October 27. Agreement No. E-6304. GA Project 20132.

4. BS EN 50126-1:2017 Railway Applications - The Specification and Demonstration of Reliability, Availability, Maintainability and Safety (RAMS) - Generic RAMS Process.

5. BS EN 50126-2:2017 Railway Applications - The Specification and Demonstration of Reliability, Availability, Maintainability and Safety (RAMS) - Systems Approach to Safety. 
6. IEC/TR 62278-3(2010) Railway applications - Specification and demonstration of reliability, availability, maintainability and safety (RAMS) - Part 3: Guide to the application of IEC 62278 for rolling stock RAM.

7. IEC/TR 62278-4(2016) Railway applications - Specification and demonstration of reliability, availability, maintainability and safety (RAMS) - Part 4: RAM risk and RAM life cycle aspects.

8. IEC 62279(2015) Railway applications - Communication, signalling and processing systems - Software for railway control and protection systems.

9. IEC 62425(2007) Railway applications - Communication, signalling and processing systems - Safety related electronic systems for signalling.

10. PD CLC/TR 50506-1:2007 Railway applications - Communication, signalling and processing systems - Application Guide for EN 50129 - Part 1: Cross-acceptance.

11. PD CLC/TR 50506-2:2009 Railway applications - Communication, signalling and processing systems - Application Guide for EN 50129 - Part 2: Safety assurance.

12. PD CLC/TR 50451:2007 Railway applications - Systematic allocation of safety integrity requirements.

13. IEC 62280(2014) Railway applications - Communication, signalling and processing systems - Safety related communication in transmission systems.

14. IEC 60300-3-3(2017) Dependability management - Part 3-3: Application guide - Life cycle costing.

15. ISO/TS 22163:2017 Railway applications - Quality management system - Business management system requirements for rail organizations: ISO 9001:2015 and particular requirements for application in the rail sector.

\section{Information about the authors:}

Pavel A. Plekhanov, Candidate of Engineering Science, Associate Professor;

9 Moskovsky av., St. Petersburg, Russia, 190031;

eLibrary SPIN: 1532-9427; ORCID: 0000-0002-2546-259X;

E-mail: pavelplekhanov@gmail.com

Vladimir V. Shmatchenko, Candidate of Engineering Science;

eLibrary SPIN: 5152-2090; ORCID: 0000-0001-6963-7286;

E-mail: vshmat45@mail.ru

\section{Сведения об авторах:}

Плеханов Павел Андреевич, кандидат технических наук, доцент;

Россия, 190031, г. Санкт-Петербург, Московский пр., д. 9;

eLibrary SPIN: 1532-9427; ORCID: 0000-0002-2546-259X;

E-mail: pavelplekhanov@gmail.com 
Шматченко Владимир Владимирович, кандидат технических наук;

eLibrary SPIN: 5152-2090; ORCID: 0000-0001-6963-7286;

E-mail:vshmat45@mail.ru

\section{To cite this article:}

Plekhanov PA, Shmatchenko VV. Standardization of Maglev Transportation Systems in Russia. Transportation Systems and Technology. 2018;4(4):32-43. doi: 10.17816/transsyst20184432-43

\section{Цитировать:}

Плеханов П.А., Шматченко В.В. Стандартизация магнитолевитационных транспортных систем в России // Транспортные системы и технологии. - 2018. - Т. 4. - № 4. - С. 32-43. doi: 10.17816/transsyst20184432-43 